\title{
Dental caries and related factors in Brazilian children from fluoridated and non-fluoridated areas
}

\author{
Cárie dentária e fatores relacionados em crianças brasileiras \\ de região com água fluoretada e não fluoretada
}

\begin{abstract}
Purpose: To compare the caries prevalence, saliva buffering capacity (SBC), oral hygiene $(\mathrm{OH})$, dietary habits, family income (FI) and frequency of visits to a dental office (Do) between Brazilian children living in areas with and without fluoridated public water supply.

Methods: Forty-six 5-7-year-old preschoolers were selected in Itatiba, SP, Brazil; 19 were from a fluoridated area, and 27 were from a non-fluoridated area. The caries index was determined according to the World Health Organization criteria, and the SBC was assessed by titration with hydrochloric acid. The $\mathrm{Fl}$, frequency of $\mathrm{OH}$ and visits to Do were estimated by questionnaire. The dietary habits were assessed with a diet chart. The differences between the groups were analyzed with Mann-Whitney-U tests $(\alpha=0.05)$.

Results: Children from the non-fluoridated area showed significantly higher dmft/DMFT than those from the fluoridated area, but they showed significantly lower SBC, $\mathrm{OH}$ frequency and FI. No significant differences were observed between the areas for dietary habits and visits to Do.

Conclusion: Children from fluoridated areas showed higher salivary buffering capacity, family income and oral hygiene frequency as well as lower caries prevalence, supporting the beneficial effect of fluoride in the tap water for caries prevention.
\end{abstract}

Key words: Dental caries; fluoride; diet; saliva; buffers

\section{Resumo}

Objetivo: Comparar prevalência de cárie, capacidade tamponante da saliva (CTS), higiene bucal (HB), hábitos dietéticos, renda familiar (RF) e frequência de visita a consultórios odontológicos (Co) entre crianças brasileiras residentes em áreas de água de abastecimento público fluoretadas e não fluoretadas.

Metodologia: Quarenta e seis crianças entre 5-7 anos foram selecionadas em Itatiba-SP-Brasil, sendo 19 pertencentes à área fluoretada e 27 à área não fluoretada. O índice de cárie foi determinado de acordo com o critério da Organização Mundial de Saúde e a CTS foi medida por titulação com ácido clorídrico. A RF, frequência de HB e visita ao Co foram estimadas por questionário. Os hábitos dietéticos foram avaliados com diário de dieta. As diferenças entre as variáveis foram analisadas pelo teste de Mann Whitney $(\alpha=0,05)$.

Resultados: As crianças da área não fluoretada apresentaram significativamente maior ceod/ CPOD que àquelas da área fluoretada, porém significativamente menor CTS, HB e RF. Com relação a hábitos dietéticos e visitas ao Co, não foi observada diferença significativa entre as áreas.

Conclusão: As crianças da área fluoretada apresentaram maior capacidade tamponante da saliva, renda familiar e frequência de higiene bucal, assim como menor prevalência de cárie, reforçando o efeito benéfico do flúor nas águas de abastecimento para prevenir a cárie.

Palavras-chave: Cárie dentária; flúor; dieta; saliva; tampão

\author{
Thaís Manzano Parisotto a \\ Luciana Maria P. da S. R. Fernandes b \\ Fabíola Galbiatti de Carvalho c \\ Eliete de Oliveira Coelho d \\ Marinês Nobre-dos-Santos a \\ Olga Maria M. de Faria Oliveira e \\ Sandra Regina Pombeiro Sponchiadoe
}

\begin{abstract}
a Department of Pediatric Dentistry, Piracicaba Dental School, University of Campinas, Piracicaba, SP, Brazil

b Department of Stomatology, Faculty of Dentistry of Bauru, University of São Paulo, Bauru, SP, Brazil

c Department of Dental Materials, Piracicaba Dental School, University of Campinas, Piracicaba, SP, Brazil

${ }^{d}$ City Hall of Itatiba, Itatiba, SP, Brazil

e Department of Biochemistry and Chemical Technology, Araraquara Chemical Institute, State University of São Paulo, Araraquara, SP, Brazil
\end{abstract}

\author{
Correspondence: \\ Sandra Regina Pombeiro Sponchiado \\ Rua Prof. Francisco Degni s/n \\ Araraquara, SP - Brazil \\ 14801-970 \\ E-mail: sponchia@iq.unesp.br
}

Received: April 30, 2010

Accepted: September 27, 2010

Conflict of Interest Statement: The authors state that there are no financial and personal conflicts of interest that could have inappropriately influenced their work.

Copyright: (C) 2010 Parisotto et al. licensee EDIPUCRS. This is an Open Access article distributed under the terms of the Creative Commons AttributionNoncommercial-No Derivative Works 3.0 Unported License. 


\section{Introduction}

Dental caries is an infectious-contagious disease that affects a large part of the world population. Together with fluorosis, periodontal disease and occlusal disorders, it is one of the main public health problems in Brazil (1).

The etiology of dental caries is multifactorial and mainly associated with cariogenic biofilm, inadequate diet and deficient oral hygiene (2). Socioeconomic and cultural factors (3) as well as saliva buffering capacity (4) are also involved in the process. Caries occurs when there is an imbalance between demineralization and remineralization of dental tissues. To prevent the $\mathrm{pH}$ from decreasing to a critical level, saliva contains specific buffer mechanisms such as bicarbonate, phosphate and some protein systems, which have a buffering effect that neutralizes the acids produced by bacteria and also have the ability to automatically eliminate certain bacterial components that require a very low $\mathrm{pH}$ to survive (5). Additionally, a high saliva buffer capacity may result in an elevated surface $\mathrm{pH}$ on the enamel interface, resulting in favorable conditions for mineral uptake (6) and consequent reduction in caries susceptibility.

The use of fluoride in tap water and toothpastes has led to a decline in caries prevalence and also to a nonuniform distribution of this disease, resulting in a polarization of caries prevalence such that many children do not have any caries, while a smaller group has a very high caries prevalence (7).

The population can be provided with fluoride in many ways: public water supply, topical application, mouth rinses, toothpastes and supplements. Fluoridation of the public water supply (tap water fluoridation) is one of the most effective public health measures related to caries prevention (8-10). Since 1974, tap water fluoridation has been mandatory in Brazil, but it has only been progressively implemented since the mid-1980s. Today, nearly one hundred million people in Brazil, more than $50 \%$ of the entire population, drink fluoridated water (11).

There are many studies available in the scientific literature that compare dental caries prevalence in fluoridated and non-fluoridated tap water areas (12-14). However, few of them have considered caries-related factors that could also influence the oral health conditions in these areas, such as the buffer capacity of saliva, family income, oral hygiene, diet and visits to a dental office. The identification of factors associated with caries risk is very important to guide the implementation of effective public health preventive procedures. In this context, the purpose of this study was to compare the prevalence of caries, saliva buffering capacity, oral hygiene frequency, dietary habits and family income of Brazilian children living in areas with and without fluoridated tap water.

\section{Methods}

This study was approved by the Ethical Committee of Research of Piracicaba Dental School (Protocol number
015/2006), Piracicaba, SP, Brazil, in accordance with the ethical principles of the Helsinki declaration of the World Medical Association. In addition, informed consent was obtained from the children's parents.

\section{Subjects}

Forty-six children of ages 5 to 7 years living in Itatiba, SP, Brazil, were included. Children from this age range were chosen because an adequate volume of saliva without stimulation could be collected to perform the salivary buffering capacity analysis. The convenience sample consisted of children from the largest public school in the fluoridated area (urban) and the two largest schools in the non-fluoridated area (rural). All children of this age range were invited to take part in this research, but only those whose parents had signed the informed consent form were included. Among the 70 invited children, 35 were from the fluoridated area, and 35 were from the non-fluoridated area. Four children were not included because it was not possible to collect their saliva. Among the remaining 66 children, only 46 filled out the questionnaire and diet chart completely. Thus, the final number of the sample was 46 children, 27 from the non-fluoridated area (13 boys and 14 girls) and 19 from the fluoridated area ( 8 boys and 11 girls).

\section{Caries assessment}

To determine the number of decayed, missing and filled deciduous and permanent teeth (dmft/DMFT), each child, seated on a chair, was examined by one Public Service dentist from Itatiba, under natural light, with a mouth mirror and ball-ended probe, in accordance with the World Health Organization (WHO) criteria (15). Prior to the beginning of the study, theoretical discussions using clinical photographic slides were held to inform the examiner about the use of the criteria and the examination method. Then, training exercises were performed and replicate examinations were carried out on a random sample of 12 preschoolers, within one week. The intra-examiner reliability was calculated using Kappa scores and recorded as 0.92 .

\section{Collection of saliva}

Approximately $5 \mathrm{~mL}$ of saliva was collected without previous stimulation in disposable plastic cups. Afterwards, it was transferred to glass tubes using disposable pipettes. These tubes were sealed and maintained in refrigerated boxes $\left(4^{\circ} \mathrm{C}\right)$ until the analysis was performed, in order to prevent the release of carbon dioxide, which could affect the $\mathrm{pH}$ measurements.

\section{Analysis of salivary buffering capacity}

Saliva buffering capacity (SBC) was assessed according to Ericsson's (16) (1949) method, by titration with $0.02 \mathrm{M}$ hydrochloric acid until reaching approximately $\mathrm{pH} 4$, as measured by a digital $\mathrm{pH}$ meter (Orion Analyzer Model $420 \mathrm{~A}$, USA). The SBC values were expressed as the total amount of hydrochloric acid $(\mathrm{mL})$ consumed in the titration extrapolated to $100 \mathrm{~mL}$ of saliva. 


\section{Questionnaire/diet chart}

The children's parents were asked to complete a standardized questionnaire to collect information about visits to a dental office and the daily frequency of their child's oral hygiene. Income data were obtained with the question, "How much is the family income per month?", and the values were expressed in Brazilian currency $(1$ real=half dollar). In order to determine the children's dietary habits, such as daily frequency of sweets (candies, cookies, chocolates), soft drink, fruit and vegetable consumption, the mothers were asked to fill out a diet chart for three consecutive days. Using this chart, the daily frequency of sweets, soft drink, fruit and vegetable consumption was calculated.

\section{Statistical analysis}

The data were tabulated, and scores were calculated for some of the quantitative and qualitative variables (oral hygiene frequency, dietary habits and visits to a dental office). The scoring scheme is shown in Table 1. Additionally, the mean and standard deviations were calculated for the dmft/DMFT index, SBC and family income data. The Mann-Whitney $\mathrm{U}$ test was performed in order to compare all the above variables between fluoridated and non-fluoridated areas, with a significance level of 0.05 .

\section{Results}

Table 2 presents the dmft/DMFT index, family income and salivary buffering capacity of children from nonfluoridated and fluoridated areas. The data showed that the $\mathrm{dmft} / \mathrm{DMFT}$ index in children from the non-fluoridated area was significantly higher compared with children from fluoridated area $(P<0.05)$. Moreover, there was also a statistically significant difference between the children from the two areas regarding family income and salivary buffering capacity $(P<0.05)$, with lower values in children from the non-fluoridated area (Table 2). As can be seen in Figure 1, about 19\% of children from the non-fluoridated area were caries free, in comparison with $58 \%$ of those from the fluoridated area.

Table 1. Criteria for scoring qualitative variables used in this study.

\begin{tabular}{|c|c|c|c|c|}
\hline Variables & Score 0 & Score 1 & Score 2 & Score 3 \\
\hline Oral Hygiene & Unanswered question & $1 x /$ day & $2 x /$ day & $3-4 x / d a y$ \\
\hline Sweets consumption & Less than $1 x /$ day & $1 x /$ day & $2-3 x / d a y$ & $4 \mathrm{x} /$ day or more \\
\hline Soft drink consumption & Less than $1 x /$ day & $1 x /$ day & $2-3 x /$ day & $4 \mathrm{x} /$ day or more \\
\hline Fruit consumption & Less than $1 x /$ day & $1 x /$ day & $2-3 x / d a y$ & $4 \mathrm{x} /$ day or more \\
\hline Vegetable consumption & Less than $1 x /$ day & $1 x /$ day & $2-3 x / d a y$ & $4 \mathrm{x} /$ day or more \\
\hline Visits to dental office & Unanswered question & No & yes & not determined \\
\hline
\end{tabular}

Table 2. Mean and standard deviations for the $\mathrm{dmft} / \mathrm{DMFT}$ index, SBC and family income data in fluoridated and non-fluoridated areas.

\begin{tabular}{lccc}
\hline \multicolumn{1}{c}{ Variables } & $\begin{array}{c}\text { Fluoridated area } \\
\text { mean } \pm \text { SD }\end{array}$ & $\begin{array}{c}\text { Non-fluoridated area } \\
\text { mean } \pm S D\end{array}$ & $P$-value \\
\hline dmft/DMFT & $1.6 \pm 2.4$ & $5.2 \pm 4.7$ & $0.004^{*}$ \\
Family income (reais) & $1126.3 \pm 946.8$ & $566.3 \pm 397.4$ & $0.032^{*}$ \\
Saliva Buffering Capacity & $121.1 \pm 31.9$ & $90.4 \pm 37.8$ & $0.007^{*}$ \\
\hline (mL HCL/100 mL saliva) & & \\
\hline
\end{tabular}

* Statistically different values $(P<0.05)$

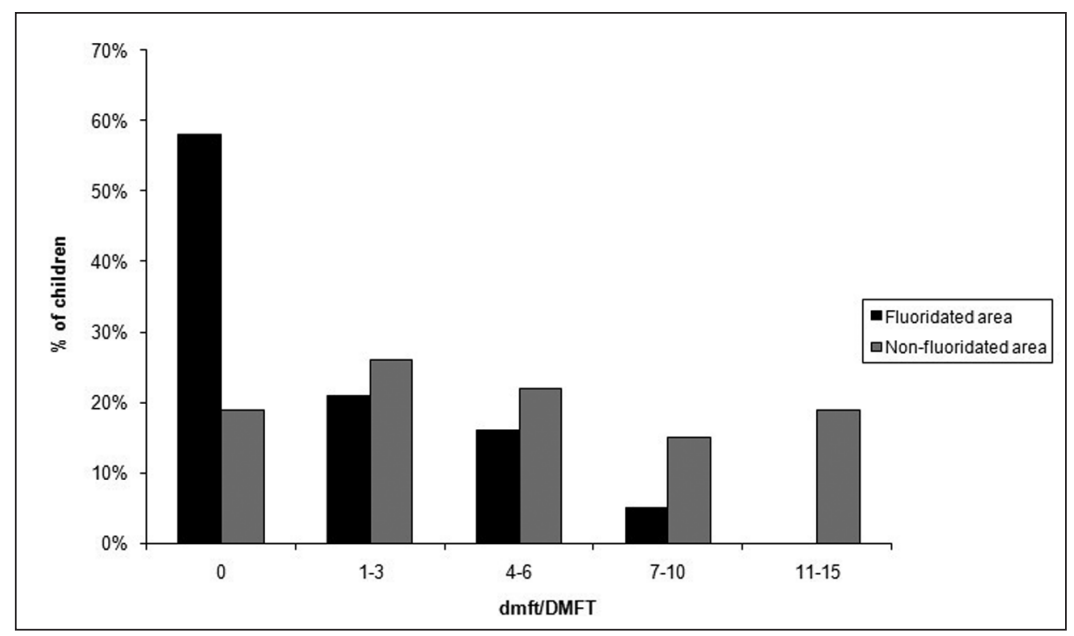

Fig. 1. Distribution (\%) of the $\mathrm{dmft} / \mathrm{DMFT}$ index for the children from fluoridated and non-fluoridated areas. 


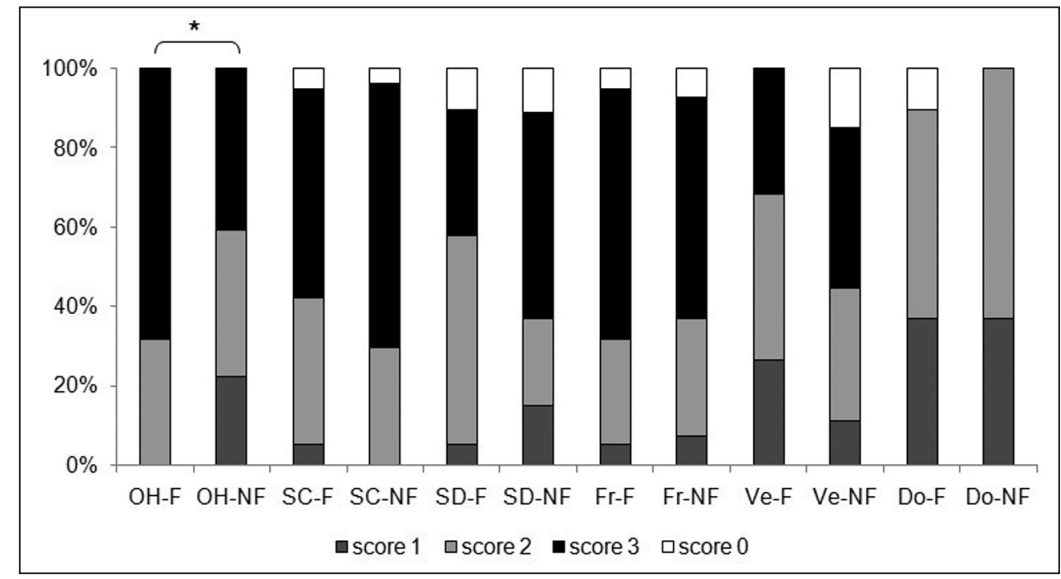

* Statistically different values $(P<0.05)$.
Fig. 2. Score percentages for oral hygiene $(\mathrm{OH})$, sweets consumption (SC), soft drink consumption (SD), fruit consumption ( $\mathrm{Fr}$ ), vegetable consumption $(\mathrm{Ve})$ and visits to dental office (Do) data in fluoridated (F) and non-fluoridated (NF) areas.
Figure 2 summarizes the data related to daily frequency of sweets, soft drink, fruit and vegetable consumption, oral hygiene and visits to a dental office. The results confirmed that the oral hygiene frequency in the fluoridated area was significantly higher $(P=0.047)$ than in the non-fluoridated. Moreover, there was no statistically significant difference $(P>0.05)$ between the two areas concerning visits to a dental office and dietary habits.

\section{Discussion}

This study was conducted in Brazilian children from Itatiba-SP, Brazil. In this community, the water supply in the urban area has been optimally fluoridated since 1980 and its heterocontrol verified that the levels of fluoride ranged from 0.6 to $0.8 \mathrm{ppm}$ during the present research. In contrast, the rural area is still deprived of water fluoridation, which may have contributed to the high dmft/DMFT index among children living in this area (Fig. 1). This result is in line with previous studies carried out in Brazilian and other communities demonstrating that children from fluoridated tap water areas have a lower caries index compared to children from areas with low or no fluoride concentration in the public water supply $(8,9,13,17-19)$ (Table 2).

The difference in socio-economic status in fluoridated and non-fluoridated areas has already been reported in the literature. Peres et al. $(3,9)$ verified that low income people in non-fluoridated towns were about $40 \%$ more prevalent, which is in agreement with our findings. It is also important to highlight that a significantly higher caries index was found in children from the non-fluoridated area, as well as a significantly lower family income (Table 2). In general, areas with a higher caries prevalence also have a lower income and lower human/child development index (3). Furthermore, Stephenson et al. (20) recently found that socio-economic class and fluoridation status were the strongest predictors of primary caries. Still, there are specific demographic aspects in the Itatiba non-fluoridated area, such as the geographic mobility of families during the harvest time, that could lead to children's moving from one school to another, thus promoting conditions that are unfavorable to the implementation of self-care procedures. This lack of self-dental care may also have contributed to the higher caries index in the non-fluoridated area.

Concerning the saliva properties, although the salivary buffering capacity is inherent to each individual, the present study found significantly higher SBC values in children from the fluoridated area (Table 2). These children also showed a higher frequency of oral hygiene practices $(P<0.05-$ Fig. $2)$. The relationship between a higher frequency of oral hygiene practices and caries prevalence has already been verified (21). Regarding SBC, whereas some studies showed no relationship between SBC and dental caries $(22,23)$, others demonstrated that there is an association between them $(24,25)$. However, SBC in Brazilian children with different $\mathrm{dmft} / \mathrm{DMFT}$ index values from fluoridated and nonfluoridated areas had never been tested before. The present investigation showed significant differences in SBC values and in the frequency of oral hygiene practices between children from the two areas (Table 2). This suggests that not only fluoride but also other factors inherent to the individuals should be considered for evaluating caries susceptibility. Because this was a preliminary study, further studies are necessary to confirm our findings.

Despite the fact that the availability of fruits and vegetables is higher in the non-fluoridated (rural) area and the access to sweets such as candies, chocolates and soft drinks is favored in the fluoridated area (urban), the urbanization process provides the development of local markets, leading to dietary changes. For this reason, the present study did not show significant differences in the daily frequency of sweets consumption between the two areas (Fig. 2).

In relation to visits to a dental office, there was no statistically significant difference between the two areas (Fig. 2). Although it is easier for people to visit a dental office in the fluoridated (urban) area, the Oral Health Department offered a mobile dental unit for dental assistance in the nonfluoridated area before this research began, which could 
explain the lack of a statistically significant difference in visits. Moreover, the Itatiba Oral Health Program includes preventive procedures in schools of both regions.

The present results showed that water fluoridation may still be a relevant public health measure in the Brazilian rural population, where oral hygiene practices are poor and the lifestyle results in high caries prevalence. The results of this investigation may also be able to contribute to the strategic planning of the Oral Health Program in Itatiba and to guide oral health actions in children who do not have the benefit of fluoridated tap water.

One of the limitations of this study is that it was crosssectional. Therefore, it did not consider the child's response to a specific factor during the disease development. In addition, the sample size may not be representative of the studied population and future studies should be conducted with a high number of children to reaffirm our findings.

\section{Conclusions}

In conclusion, the present study showed that children from the fluoridated area had higher salivary buffering capacity, family income and frequency of oral hygiene practices as well as lower caries prevalence. These results support the beneficial effect of fluoride in the tap water for caries prevention. This study was the first to show that there was a significant difference between the salivary buffering capacities of children living in fluoridated and non-fluoridated areas.

\section{Acknowledgments}

The authors would like to thank Maria Cristina Alves de Siqueira, the Oral Hygiene Technician, for her support during collection of the children's saliva. We also thank the Department of Health and Education of Itatiba, SP, Brazil.

\section{References}

1. Cangussu MCT, Coelho EO, Castellanos RAF. Epidemiology and inequalities in oral health at 5, 12 and 15 years old in Itatiba- SP. J Appl Oral Sci $2001 ; 9: 77-85$.

2. Selwitz RH, Ismail AI, Pitts NB. Dental caries. Lancet 2007;369: 51-9.

3. Peres MA, Peres KG, Antunes JLF, Junqueira SR, Frazão P, Narvai PC. The association between socioeconomic development at the town level and the distribution of dental caries in Brazilian children. Pan Am J Public Health 2003;14:149-57.

4. Aiuchi H, Kitasako Y, Fukuda Y, Nakashima S, Burrow MF, Tagami J. Relationship between quantitative assessments of salivary buffering capacity and ion activity product for hydroxyapatite in relation to cariogenic potential. Aust Dent J 2008;53:167-71.

5. Llena-Puy $C$. The rôle of saliva in maintaining oral health and as an aid to diagnosis. Med Oral Patol Oral Cir Bucal 2006;11: E449-55.

6. Ericsson Y. Clinical investigations of the salivary buffering action. Acta Odontol Scand 1959;17:131-65

7. Narvai PC, Frazão P, Roncalli AG, Antunes JL. Dental caries in Brazil: decline, polarization, inequality and social exclusion. Rev Panam Salud Publica 2006;19:385-93.

8. Tagliaferro EPS, Cypriano S, Sousa, ML, Wada RS. Caries experience among school children in relation to community fluoridation status and town size. Acta Odontol Scand 2004;62:124-8.

9. Peres MA, Antunes JL, Peres KG. Is water fluoridation effective in reducing inequalities in dental caries distribution in developing countries? Soz Präventivmed 2006;51:302-10.

10. Pizzo G, Piscopo MR, Pizzo I, Giuliana G. Community water fluoridation and caries prevention: a critical review. Clin Oral Invest 2007;1 1:189-93.

11. Antunes JLF, Peres MA, Mello TRC, Waldman EA. Multilevel assessment of determinants of dental caries experience in Brazil. Community Dent Oral Epidemiol 2006;34:146-52.

12. Lee $M$, Dennison PJ. Water fluoridation and dental caries in 5 and 12- year-old children from Catenburry and Wellington. New Zealand Dent J 2004;100:10-5.
13. Cypriano S, Pecharki GD, Sousa MLR, Wada RS. Oral health of schoolchildren residing in areas with or without water fluoridation in Sorocaba. Cad Saúde Pública 2003;19:1063-71.

14. Ely HC, Pretto SM. Fluorose e cárie dentária: estudo epidemiológico em cidades do Rio Grande do Sul com diferentes níveis de flúor nas águas de abastecimento. Rev Odonto Cienc 2000;31:143-73.

15. World Health Organization. Oral health surveys, basic methods. $4^{\text {th }}$ ed. Geneva: World Health Organization; 1997

16. Ericsson Y. Enamel apatite solubility. Acta Odontol Scand 1949;8: 1 - 139.

17. Sampaio FC, Hossain AN, von der Fehr FR, Arneberg P. Dental caries and sugar intake of children from rural areas with different water fluoride levels in Paraíba, Brazil. Community Dent Oral Epidemiol 2000;28: 307-13.

18. Foster GR, Downer MC, Lunt M, Aggarwal V, Tickle M. Predictive tool for estimating the potential effect of water fluoridation on dental caries. Community Dent Health 2009;26:5-1 1 .

19. Spencer AJ, Armfield JM, Slade GD. Exposure to water fluoridation and caries increment. Community Dent Health 2008;25:12-22.

20. Stephenson J, Chadwick BL, Playle RA, Treasure ET. Modelling childhood caries using parametric competing risks survival analysis methods for clustered data. Caries Res 2010;44:69-80.

21. Tsai Al, Chen CY, Li LA, Hsiang CL, Hsu KH. Risk indicators for early childhood caries in Taiwan. Community Dent Oral Epidemiol 2006;34:437-45.

22. Farsi N. Dental caries in relation to salivary factors in Saudi population groups. J Contemp Dent Pract 2008;9:16-23.

23. Zukanović A, Kobaslija S, Ganibegović M. Caries risk assessment in Bosnian children using Cariogram computer model. Int Dent J 2007; 57:177-83.

24. Russell JI, MacFarlane TW, Aitchison TC, Stephen KW, Burchell CK. Prediction of caries increment in Scottish adolescents. Community Dent Oral Epidemiol 1991;19:74-7.

25. Wilson RF, Ashley FP. Identification of caries risk in schoolchildren salivary buffering capacity and bacterial counts, sugar intake and caries experience as predictors of 2-year and 3-year caries increment. Br Dent J 1989;167:99-102. 